\title{
Gm Allotypes in Mother-Father-Cord Trios ${ }^{1}$
}

\section{A Selective Transfer of Autologous, Fetal IgG to the Mother}

\section{Robert C. Williams ${ }^{2}$ and Henry Gershowitz}

Department of Human Genetics, The University of Michigan Medical School, Ann Arbor, Mich.

\begin{abstract}
When tested at a standard dilution (1:30), mother-cord $\mathrm{Gm}$ phenotypes are identical. A more sensitive assay reveals that the fetus does possess paternal antigen, that is, does produce small amounts of autologous IgG. The paternal antigens, in both the mother and the cord plasma, appear in a mosaic, one that suggests the fetus has the ability to selectively transfer his own IgG subclasses to the mother.
\end{abstract}

The first studies of Gm allotype in maternal-cord sera demonstrated the identity of the paired phenotypes $[2,6]$. Since Fudenberg's subsequent observation that his fourth offspring produced autologous G1m(a) antigen, and immunized the G1m(a-) mother [4], several studies have reported the presence of nonmaternal antigens in cords.

Martensson and Fudenberg [7] reported that 5 of 14 cord sera from G3m(b-) mothers, and 12 of 33 from G1m(a-) mothers, inhibited the respective antiallotype sera at low dilutions of the cord sera. Mellbye and Natvig [8] tested 29 cord sera at a standard dilution and found five different phenotypes, each cord being identical to the mother. When 19 of the cord sera were tested again using a lower dilution, 7 had an allotype different from the maternal one. In stark

1 This work was supported by DOE contract EY-76-C-02-2828.

2 Recipient of a Postdoctoral Fellowship from NIH grant No.1T32-GM-07123 awarded to the University of Michigan. contrast to these findings are those of $R o$ partz et al. [9] who found that only two cords out of 81 produced a $\mathrm{Gm}$ allotype different from the mother but that 21 mothers possessed an allotype that was completely lacking in the cord sera. The contrast is especially striking when compared to the report of Daveau et al. [3] in which 31 of 90 cord sera possessed $\mathrm{Gm}$ antigens that the mother lacked but in no case did a mother possess an antigen that the child did not have.

The present study was an attempt to determine whether, and how often, paternal allotype appears in the cord and maternal sera. The key word is paternal because it leads to an experimental design that is different from the work that has gone before, a design that can determine the presence and frequency of autologous $\gamma$-globulin in cord sera with some certainty. Instead of screening mother-cord pairs for nonmaternal antigens, mother-father-cord trios were screened at a standard testing dilution to 
determine whether mother-cord pairs were indeed identical, and to identify those families in which the father possessed an antigen that the mother lacked and in which the cord plasma could be tested for the autologous production of IgG. Not only would this detect de novo synthesis of cord $\mathrm{IgG}$, it also allows the investigator to test maternal sera for fetal immunization and to monitor the pattern of $\mathrm{Gm}$ antigen transfer from the mother to the fetus, and from the fetus to the mother.

To detect the low levels of cord IgG (in the cord and maternal sera) an extremely sensitive assay is required. The standard hemagglutination inhibition technique was modified for this purpose. In addition, the typing of the fathers provided the necessary information to test whether all cords produce their own immunoglobulin at birth. The expected number who should, this estimate derived from the fathers's phenotypes, was compared to the observed number of cord plasma in which paternal antigen was found.

\section{Materials and Methods}

Gm allotyping of 180 families was done using standard hemagglutination inhibition techniques. Human group $\mathbf{O} R \mathrm{~h}+$ red blood cells were coated with human anti-D antibodies that included $\mathrm{Gm}$ specificities $\mathrm{G} 1 \mathrm{~m}(\mathrm{a}), \mathrm{G} 1 \mathrm{~m}(\mathrm{x}), \mathrm{G} 1 \mathrm{~m}(\mathrm{f}), \mathrm{G} 3 \mathrm{~m}(\mathrm{~g})$, $\mathrm{G} 3 \mathrm{~m}\left(\mathrm{~b}^{0}\right), \mathrm{G} 3 \mathrm{~m}\left(\mathrm{~b}^{1}\right)$, and $\mathrm{G} 3 \mathrm{~m}\left(\mathrm{~b}^{3}\right)$. One drop of a $0.02 \%$ suspension of coated red cells was added to one drop of an appropriate dilution of antiallotype serum and 1 drop of the unknown serum at 1:30 in a v-well microtiter plate (Cooke Engineering). After a 45-min incubation the plates were spun at $2,000 \mathrm{rpm}$ for $12 \mathrm{sec}$ and set at a $50^{\circ}$ angle to be read.

To improve the sensitivity of the standard technique, it was modified in the following manner, which shall be called the endpoint titration inhibition test (ETI) for low level Gm allotype determinations. Instead of using a standard dilution of antiallotype serum, the antisera were titrated through their endpoints for each test. The unknown, inhibiting plasma was defibrinated at $56^{\circ} \mathrm{C}$ for $30 \mathrm{~min}$, spun at $2,500 \mathrm{rpm}$ for $30 \mathrm{~min}$ at room temperature, and diluted 1:5 in PBS for the test. Six serial doubling dilutions of each antiallotype were inhibited with the unknown at 1:5 and the reduction of the titer of the antiallotype serum compared to a set of controls. The controls are the same dilutions of antisera inhibited 1:5 with sera that are negative for the given allotype.

The 180 families, each a mother-father-cord trio, were collected at the University of Michigan Women's Hospital and are part of a mutation study of the Department of Human Genetics, Department of Energy Contract E(11-1)-2828. All blood samples were drawn into $2 \mathrm{ml}$ of acid citrate dextrose after which the plasma were removed and stored at $-30^{\circ} \mathrm{C}$. The mother's blood was drawn before the birth of her child.

\section{Results}

The mother-father-cord plasma of the 180 families were first typed at 1:30 using the standard inhibition test for Gm allotype. In 175 of the families the mother and cord phenotypes were identical. In 5 families, $922,1036,1059,1060$, and 1083 , paternal antigen could be detected in the cord plasma at 1:30 (table I, II). Paternal G3m( $\left.b^{1}\right)$ antigen was expressed in each of the five cords, $G 3 \mathrm{~m}\left(\mathrm{~b}^{0}\right)$ in one of the five, and $\mathrm{G} 3 \mathrm{~m}\left(\mathrm{~b}^{3}\right)$ in none of the five plasma at 1:30. $G 3 m\left(b^{1}\right)$ and $G 3 m\left(b^{0}\right)$ were the only paternal allotypes detected in the cord plasma at the standard dilution.

After the phenotypes of all family members were determined at 1:30, the families were chosen in which the father possessed a $\mathrm{Gm}$ allotype that the mother lacked. In the sample, 69 families were identified as potentially informative and were tested for the presence of paternal antigen in both the 
Table 1. Presence of paternal antigen in cord plasma

\begin{tabular}{|c|c|c|c|c|c|}
\hline & Family & $\begin{array}{l}\text { Mother's phenotype } \\
1: 30 \text { and } 1: 5^{*}\end{array}$ & $\begin{array}{l}\text { Father's phenotype } \\
1: 30\end{array}$ & $\begin{array}{l}\text { Cord's phenotype } \\
1: 30\end{array}$ & $\begin{array}{l}\text { Paternal antigen in } \\
\text { cord plasma } 1: 5(\mathrm{ETI})^{*}\end{array}$ \\
\hline 1 & 955 & $\operatorname{Gm}\left(a ; b^{0}, b^{1}, b^{8}\right)$ & $\operatorname{Gm}\left(a, f ; b^{0}, b^{1}, b^{8}\right)$ & $\operatorname{Gm}\left(a ; b^{0}, b^{1}, b^{3}\right)$ & $(f+)$ \\
\hline 2 & 958 & $\operatorname{Gm}(a, x ; g)$ & $\mathrm{Gm}\left(\mathrm{f} ; \mathrm{b}^{0}, \mathrm{~b}^{\mathbf{1}}, \mathrm{b}^{\mathbf{3}}\right)$ & $\mathrm{Gm}(\mathrm{a}, \mathrm{x} ; \mathrm{g})$ & $(f-)\left(b^{0}-\right)\left(b^{1}+\right)\left(b^{8}-\right)$ \\
\hline 3 & 970 & $\mathrm{Gm}\left(\mathrm{f} ; \mathrm{b}^{0}, \mathrm{~b}^{\mathbf{1}}, \mathrm{b}^{\mathbf{3}}\right)$ & $\operatorname{Gm}\left(a, f ; g, b^{0}, b^{1}, b^{3}\right)$ & $\operatorname{Gm}\left(f ; b^{0}, b^{1}, b^{2}\right)$ & $(a+)(g-)$ \\
\hline 4 & 992 & $\operatorname{Gm}\left(a ; g, b^{0}, b^{3}\right)$ & $G m\left(a ; f, b^{0}, b^{1}, b^{3}\right)$ & $\operatorname{Gm}\left(a ; g, b^{0}, b^{1}, b^{8}\right)$ & $(f+)\left(b^{1}+\right)$ \\
\hline 5 & 994 & $\mathrm{Gm}\left(\mathrm{f} ; \mathrm{b}^{0}, \mathrm{~b}^{1}, \mathrm{~b}^{3}\right)$ & $\operatorname{Gm}\left(a, f ; g, b^{0}, b^{1}, b^{3}\right)$ & $\mathrm{Gm}\left(\mathrm{f} ; \mathrm{b}^{0}, \mathrm{~b}^{1}, \mathrm{~b}^{\mathbf{3}}\right)$ & $(a+)(g+)$ \\
\hline 6 & 1,000 & $\mathrm{Gm}\left(\mathrm{f} ; \mathrm{b}^{0}, \mathrm{~b}^{\mathrm{1}}, \mathrm{b}^{\mathrm{s}}\right)$ & $\mathrm{Gm}(\mathrm{a}, \mathrm{x} ; \mathrm{g})$ & $G m\left(f ; b^{0}, b^{1}, b^{8}\right)$ & $(a+)(x+)(g+)$ \\
\hline 7 & 1,005 & $G m\left(a, f ; g, b^{0}, b^{1}, b^{2}\right)$ & $\operatorname{Gm}\left(a, x, f ; g, b^{0}, b^{1}, b^{3}\right)$ & $G m\left(a, f ; g, b^{0}, b^{1}, b^{3}\right)$ & $(x+)$ \\
\hline 8 & 1,017 & $\mathrm{Gm}\left(\mathrm{a}, \mathrm{f} ; \mathrm{g}, \mathrm{b}^{0}, \mathrm{~b}^{1}, \mathrm{~b}^{3}\right)$ & $\mathrm{Gm}(\mathrm{a}, \mathrm{x} ; \mathrm{g})$ & $\operatorname{Gm}\left(a, f ; g, b^{0}, b^{1}, b^{8}\right)$ & $(x+)$ \\
\hline 9 & 1,018 & $G m\left(f ; b^{0}, b^{1}, b^{3}\right)$ & $G m\left(a, x, f ; g, b^{0}, b^{1}, b^{3}\right)$ & $\operatorname{Gm}\left(f ; b^{0}, b^{1}, b^{3}\right)$ & $(a+)(x+)(g+)$ \\
\hline 10 & 1,048 & $\mathrm{Gm}\left(f ; \mathrm{b}^{\mathrm{a}}, \mathrm{b}^{\mathbf{1}}, \mathrm{b}^{\mathrm{s}}\right)$ & $G m\left(a ; b^{0}, b^{1}, b^{3}\right)$ & $\operatorname{Gm}\left(f ; b^{0}, b^{1}, b^{8}\right)$ & $(a+)$ \\
\hline 11 & 1,058 & $G m\left(f ; b^{0}, b^{1}, b^{3}\right)$ & $\mathrm{Gm}(\mathrm{a}, \mathrm{x} ; \mathrm{g})$ & $\mathrm{Gm}\left(\mathrm{f} ; \mathrm{b}^{\circ}, \mathrm{b}^{1}, \mathrm{~b}^{3}\right)$ & $(a+)(g+)$ \\
\hline 12 & 1,059 & $\mathrm{Gm}(\mathrm{a} ; \mathrm{g})$ & $\mathrm{Gm}\left(\mathrm{a}, \mathbf{x}, \mathbf{f} ; \mathbf{g}, \mathrm{b}^{0}, \mathrm{~b}^{\mathbf{1}}, \mathrm{b}^{3}\right)$ & $\operatorname{Gm}\left(a ; g, b^{1}\right)$ & $\left(x^{-}\right)(f+)\left(b^{0}+\right)\left(b^{1}+\right)\left(b^{3}+\right)$ \\
\hline 13 & 1,060 & $\operatorname{Gm}(a, x ; g)$ & $\operatorname{Gm}\left(a, f ; g, b^{0}, b^{1}, b^{8}\right)$ & $\operatorname{Gm}\left(\mathbf{a}, \mathbf{x} ; \mathbf{g}, \mathbf{b}^{1}\right)$ & $(f+)\left(b^{\circ}+\right)\left(b^{1}+\right)\left(b^{3}+\right)$ \\
\hline 14 & 1,063 & $\mathrm{Gm}\left(\mathrm{f} ; \mathrm{b}^{0}, \mathrm{~b}^{1}, \mathrm{~b}^{3}\right)$ & $\operatorname{Gm}\left(a, f ; b^{0}, b^{1}, b^{a}\right)$ & $\mathrm{Gm}\left(f ; b^{0}, b^{1}, b^{8}\right)$ & $(a+)$ \\
\hline 15 & 1,064 & $\operatorname{Gm}\left(a ; g, b^{0}, b^{1}, b^{3}\right)$ & $\operatorname{Gm}\left(f ; b^{0}, b^{1}, b^{3}\right)$ & $\operatorname{Gm}\left(a ; g, b^{0}, b^{1}, b^{3}\right)$ & $(\mathrm{f}+)$ \\
\hline 16 & 1,066 & $G m\left(f ; b^{0}, b^{1}, b^{3}\right)$ & $G m\left(a, x, f ; g, b^{0}, b^{1}, b^{3}\right)$ & $\mathrm{Gm}\left(\mathrm{f} ; \mathrm{b}^{\mathrm{a}}, \mathrm{b}^{\mathrm{1}}, \mathrm{b}^{\mathrm{a}}\right)$ & $(a+)(x+)(g+)$ \\
\hline 17 & 1,075 & $\mathrm{Gm}\left(\mathrm{a} ; \mathrm{b}^{0}, \mathrm{~b}^{1}, \mathrm{~b}^{\mathrm{a}}\right)$ & $G m\left(f ; b^{0}, b^{1}, b^{3}\right)$ & $\operatorname{Gm}\left(a ; b^{0}, b^{1}, b^{3}\right)$ & $(f+)$ \\
\hline 18 & 1,079 & $G m\left(f ; b^{a}, b^{1}, b^{3}\right)$ & $\mathrm{Gm}(\mathrm{a}, \mathrm{x} ; \mathrm{g})$ & $G m\left(f ; b^{0}, b^{1}, b^{3}\right)$ & $(a+)(x-)(g+)$ \\
\hline 19 & 1,083 & $\operatorname{Gm}(a, x ; g)$ & $\operatorname{Gm}\left(a, f ; g, b^{\circ}, b^{1}, b^{3}\right)$ & $\operatorname{Gm}\left(a, x ; \mathbf{g}, b^{0}, b^{1}\right)$ & $(f+)\left(b^{0}+\right)\left(b^{1}+\right)\left(b^{3}+\right)$ \\
\hline 20 & 1,101 & $\mathrm{Gm}\left(\mathrm{a} ; \mathrm{g}, \mathrm{b}^{\mathbf{0}}, \mathrm{b}^{\mathbf{3}}\right)$ & $G m\left(f ; b^{0}, b^{1}, b^{3}\right)$ & $\operatorname{Gm}\left(a ; g, b^{0}, b^{3}\right)$ & $(f+)\left(b^{1}+\right)$ \\
\hline 21 & 1,107 & $\operatorname{Gm}(a ; g)$ & $G m\left(f ; b^{0}, b^{1}, b^{3}\right)$ & $\operatorname{Gm}(a ; g)$ & $(\mathrm{f}+)\left(\mathrm{b}^{0}+\right)\left(\mathrm{b}^{1}+\right)\left(\mathrm{b}^{3}-\right)$ \\
\hline 22 & 1,114 & $\mathrm{Gm}\left(f ; \mathrm{b}^{0}, \mathrm{~b}^{\mathbf{1}}, \mathrm{b}^{\mathbf{3}}\right)$ & $\operatorname{Gm}\left(a, f ; g, b^{0}, b^{1}, b^{3}\right)$ & $\operatorname{Gm}\left(f ; b^{0}, b^{1}, b^{3}\right)$ & $(a-)(g+)$ \\
\hline 23 & 1,116 & $\operatorname{Gm}\left(a ; g, b^{0}, b^{1}, b^{3}\right)$ & $G m\left(f ; b^{0}, b^{1}, b^{2}\right)$ & $\operatorname{Gm}\left(a ; g, b^{0}, b^{1}, b^{3}\right)$ & $(\mathbf{f}+)$ \\
\hline 24 & 1,120 & $\operatorname{Gm}\left(a, f ; b^{0}, b^{1}, b^{8}\right)$ & $\operatorname{Gm}\left(a, x, f ; g, b^{0}, b^{1}, b^{3}\right)$ & $\operatorname{Gm}\left(a, f ; b^{0}, b^{1}, b^{3}\right)$ & $(x+)(g+)$ \\
\hline 25 & 1,121 & $\operatorname{Gm}\left(f ; b^{0}, b^{1}, b^{3}\right)$ & $\operatorname{Gm}\left(a, f ; g, b^{0}, b^{1}, b^{3}\right)$ & $\mathrm{Gm}\left(\mathrm{f} ; \mathrm{b}^{0}, \mathrm{~b}^{\mathbf{1}}, \mathrm{b}^{3}\right)$ & $(a+)(g+)$ \\
\hline 26 & 1,123 & $\mathrm{Gm}(\mathrm{a} ; \mathrm{g})$ & $G m\left(f ; b^{0}, b^{1}, b^{3}\right)$ & $\mathrm{Gm}(\mathrm{a} ; \mathrm{B})$ & $(f+)\left(b^{0}+\right)\left(b^{1}+\right)\left(b^{3}-\right)$ \\
\hline 27 & 1,128 & $\operatorname{Gm}(a ; g)$ & $\operatorname{Gm}(a, x ; g)$ & $\mathrm{Gm}(\mathrm{a} ; \mathrm{g})$ & $(x+)$ \\
\hline 28 & 1,137 & $\operatorname{Gm}\left(f ; b^{0}, b^{1}, b^{3}\right)$ & $\operatorname{Gm}\left(a, f ; g, b^{0}, b^{1}, b^{9}\right)$ & $\mathrm{Gm}\left(\mathrm{f} ; \mathrm{b}^{0}, \mathrm{~b}^{\mathbf{1}}, \mathrm{b}^{\mathrm{s}}\right)$ & $(a+)(g+)$ \\
\hline 29 & 1,139 & $\mathrm{Gm}\left(\mathrm{f} ; \mathrm{b}^{0}, \mathrm{~b}^{1}, \mathrm{~b}^{8}\right)$ & $\operatorname{Gm}\left(a, x, f ; g, b^{a}, b^{1}, b^{3}\right)$ & $\operatorname{Gm}\left(f ; b^{0}, b^{1}, b^{3}\right)$ & $(a+)(x+)(g+)$ \\
\hline 30 & 1,140 & $\operatorname{Gm}(a, x ; g)$ & $G m\left(f ; b^{0}, b^{1}, b^{3}\right)$ & $\mathrm{Gm}\left(\mathrm{a}, \mathrm{x} ; \mathrm{g}, \mathrm{b}^{1}\right)$ & $(\mathrm{f} t)\left(\mathrm{b}^{0}+\right)\left(\mathrm{b}^{\mathrm{i}} t\right)\left(\mathrm{b}^{\mathrm{s}} t\right)$ \\
\hline 31 & 1,143 & $G m\left(f ; b^{0}, b^{1}, b^{3}\right)$ & $G m\left(a, f ; g, b^{0}, b^{1}, b^{3}\right)$ & $\mathrm{Gm}\left(\mathrm{f} ; \mathrm{b}^{\circ}, \mathrm{b}^{\mathbf{1}}, \mathrm{b}^{\mathbf{3}}\right)$ & $(a+)(g+)$ \\
\hline 32 & 1,003 & $\operatorname{Gm}\left(f ; b^{0}, b^{1}, b^{3}\right)$ & $\operatorname{Gm}\left(a, x, f ; g, b^{0}, b^{1}, b^{3}\right)$ & $G m\left(f ; b^{0}, b^{1}, b^{3}\right)$ & $(a+)(x+)(g+)$ \\
\hline
\end{tabular}

* Mother and cord were tested 1:5 using the endpoint titration inhibition test (ETI).

mother and the cord using the endpoint titration inhibition test. Presence of paternal antigen in the cord serum of such a family was taken as evidence of autologous production of fetal immunoglobulin. Paternal allotype was found in 41 of the 69 cord samples and in 9 of the maternal sera (table I, II).
The pattern of paternal $\mathrm{Gm}$ specificities in the cord and maternal sera, which one can only call a mosaic, merits close attention.

The G3m(b) complex of three linked alleles does not always occur together in the cord sera. In cord serum 958 only the 
Table I. Presence of paternal antigen in cord and maternal sera

\begin{tabular}{|c|c|c|c|c|c|}
\hline & Family & $\begin{array}{l}\text { Mother's } \\
\text { phenotype 1:30 }\end{array}$ & $\begin{array}{l}\text { Father's phenotype } \\
1: 30\end{array}$ & $\begin{array}{l}\text { Cord's phenotype } \\
1: 30\end{array}$ & $\begin{array}{l}\text { Paternal antigens in Cord or } \\
\text { maternal sera 1:5 (ETI) }\end{array}$ \\
\hline 1 & 954 & $\operatorname{Gm}\left(f ; b^{0}, b^{1}, b^{8}\right)$ & $\operatorname{Gm}\left(a, x, f ; g, b^{0}, b^{1}, b^{2}\right)$ & $\operatorname{Gm}\left(f ; b^{0}, b^{1}, b^{3}\right)$ & $\begin{array}{lr}\text { cord } 954 & (a-)(x-)(g+) \\
\text { mother } & 954(a+)(x-)(g+)\end{array}$ \\
\hline 2 & 960 & $G m\left(a ; b^{0}, b^{1}, b^{8}\right)$ & $G m\left(a, f ; g, b^{a}, b^{1}, b^{2}\right)$ & $G m\left(a ; b^{0}, b^{1}, b^{8}\right)$ & $\begin{array}{l}\text { cord } 960 \quad(g-)(f-) \\
\text { mother } 960(g+)(f+)\end{array}$ \\
\hline 3 & 973 & $\mathrm{Gm}(\mathrm{a}, \mathrm{x} ; \mathrm{g})$ & $\mathrm{Gm}\left(\mathrm{a}, \mathrm{f} ; \mathrm{g}, \mathrm{b}^{0}, \mathrm{~b}^{\mathbf{1}}, \mathrm{b}^{3}\right)$ & $G m(a, x ; g)$ & $\begin{array}{l}\text { cord } 973(f+)\left(b^{a}\right)\left(b^{2}\right)\left(b^{3}-\right) \\
\text { mother } 973(f-)\left(b^{0}-\right)\left(b^{1}\right)\left(b^{2}-\right)\end{array}$ \\
\hline 4 & 997 & $\mathrm{Gm}\left(\mathrm{a} ; \mathrm{b}^{0}, \mathrm{~b}^{\mathbf{1}}, \mathrm{b}^{\mathbf{3}}\right)$ & $\operatorname{Gm}\left(a, f ; g, b^{0}, b^{1}, b^{a}\right)$ & $G m\left(a ; b^{0}, b^{1}, b^{0}\right)$ & $\begin{array}{l}\text { cord } 997(f+)(g-) \\
\text { mother } 997(f+)(g-)\end{array}$ \\
\hline 5 & 1,013 & $\operatorname{Gm}\left(a, f ; b^{0}, b^{1}, b^{3}\right)$ & $\operatorname{Gm}\left(a, \mathbf{x}, \mathbf{f} ; \mathbf{g}, \mathrm{b}^{0}, \mathrm{~b}^{\mathbf{1}}, \mathrm{b}^{\mathbf{8}}\right)$ & $G m\left(a, f ; b^{0}, b^{1}, b^{3}\right)$ & $\begin{array}{l}\text { cord } 1,013 \quad(\mathrm{~g}+)(\mathrm{x}-) \\
\text { mother } 1,013(\mathrm{~g}+)(\mathrm{x}-)\end{array}$ \\
\hline 6 & 1,036 & Gm(a;g) & $G m\left(a, f ; b^{0}, b^{1} b^{3}\right)$ & $\mathrm{Gm}\left(\mathrm{a} ; \mathbf{g}, \mathrm{b}^{\mathbf{1}}\right)$ & $\begin{array}{l}\text { cord } 1,036(f+)\left(b^{a}+\right)\left(b^{1}+\right)\left(b^{3}+\right) \\
\text { mother } 1,036(f+)\left(b^{a}+\right)\left(b^{1}+\right)\left(b^{3}\right)\end{array}$ \\
\hline 7 & 1,092 & $G m\left(f ; b^{0}, b^{1}, b^{3}\right)$ & $G m\left(a, f ; g, b^{0}, b^{1}, b^{g}\right)$ & $G m\left(f ; b^{0}, b^{1}, b^{8}\right)$ & $\begin{array}{l}\text { cord } 1,092 \quad(\mathrm{a}+)(\mathrm{g}-) \\
\text { mother } 1,092(\mathrm{a}+)(\mathrm{g}+)\end{array}$ \\
\hline 8 & 1,097 & $\mathrm{Gm}(\mathbf{a} ; \mathbf{g})$ & $\mathrm{Gm}\left(\mathrm{a}, \mathrm{f} ; \mathrm{g}, \mathrm{b}^{\mathrm{o}}, \mathrm{b}^{1}, \mathrm{~b}^{3}\right)$ & $\mathrm{Gm}(\mathrm{a} ; \mathrm{g})$ & $\begin{array}{l}\text { cord } 1,097(f-)\left(b^{0}-\right)\left(b^{1}-\right)\left(b^{3}+\right) \\
\text { mother } 1,097(f-)\left(b^{0}-\right)\left(b^{1}+\right)\left(b^{3}-\right)\end{array}$ \\
\hline 9 & 1,102 & $G m\left(f ; b^{0}, b^{1}, b^{3}\right)$ & $G m\left(a, f ; g, b^{0}, b^{1}, b^{\mathbf{s}}\right)$ & $G m\left(f ; b^{0}, b^{1}, b^{8}\right)$ & $\begin{array}{l}\text { cord } 1,102 \quad(\mathrm{a}-)(\mathrm{g}+) \\
\text { mother } 1,102(\mathrm{a}+)(\mathrm{g}+)\end{array}$ \\
\hline
\end{tabular}

$\mathrm{G} 3 \mathrm{~m}\left(\mathrm{~b}^{1}\right)$ antigen is present; in cords 1107 and 1123 the $\mathrm{G} 3 \mathrm{~m}\left(\mathrm{~b}^{8}\right)$ is absent although it is present in the sera of both fathers. When one includes the mothers the pattern of inheritance and transplacental transmittance becomes even more complicated. In family

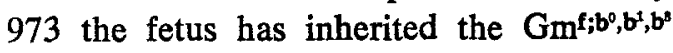
haplotype from the father but expresses only the G1m(f) antigen. Mother 973, in contrast, expresses the paternal $\mathrm{G} 3 \mathrm{~m}\left(\mathrm{~b}^{1}\right)$ antigen but neither G3m( $\left.b^{0}\right)$ or $G 3 m\left(b^{3}\right)$. In family 1036 the fetus expresses all four antigens of the haplotype but the mother lacks the $\mathrm{G} 3 \mathrm{~m}\left(\mathrm{~b}^{3}\right)$ antigen. Only $\mathrm{G} 3 \mathrm{~m}\left(\mathrm{~b}^{3}\right)$ is found in cord 1097 , whereas the mother has only $\mathrm{G} 3 \mathrm{~m}\left(\mathrm{~b}^{1}\right)$.

A similar mosaic is found when one considers the inheritance and transmission of the $\mathrm{Gm}^{\mathrm{a} ; \mathrm{z}}$ and $\mathrm{Gm}^{\mathrm{a}, \mathrm{x} ; \mathrm{g}}$ haplotypes. In cord $970 \mathrm{G} 1 \mathrm{~m}(\mathrm{a})$ is present but not $\mathrm{G} 3 \mathrm{~m}(\mathrm{~g})$; in cord 1114 no $\mathrm{G} 1 \mathrm{~m}(\mathrm{a})$ is found but $\mathrm{G} 3 \mathrm{~m}(\mathrm{~g})$ is clearly present. Mother-cord pairs are even more interesting. Family 954 cord serum has only $\mathrm{G} 3 \mathrm{~m}(\mathrm{~g})$ but the mother has both G1m(a) and G3m(g). Cord 1092 has G1m(a) but not G3m(g). Mother 1092 has both. Mother 1102 also has both G1m(a) and $\mathrm{G} 3 \mathrm{~m}(\mathrm{~g})$ antigens but the corresponding cord has only G3m(g).

The mosaic pattern in the data led the authors to question the reliability of the ETI test; that is, was the endpoint titration inhibition test giving false positives or false negatives. This can be determined by comparing the observed frequencies of paternal antigen in the cord sera with the expected proportion, calculated from the frequencies of the fathers' genotypes and phenotypes, and by testing a selected group of fathers' 
Table III. Inheritance of paternal antigen by the cord

\begin{tabular}{llc}
\hline Father & Expected & Observed \\
\hline Homozygous (10) & 10 & 10 \\
Heterozygous (51) & 25.5 & 27 \\
Ambiguous (8) $\mathrm{Gm}(\mathrm{a}, \mathrm{x} ; \mathrm{g})$ & 5 & 4 \\
\hline
\end{tabular}

plasma at 1:5 for the $\mathrm{Gm}$ antigens that they lacked at 1:30.

Among the 69 informative families, 51 had a father heterozygous for the paternal haplotype of interest, 10 a father who was homozygous for a haplotype different from the mother, and 8 fathers who were $\mathrm{Gm}(\mathrm{a}, \mathrm{x} ; \mathrm{g})$. The number of children born with a paternal antigen different from the mother closely matched the theoretical expectations (table III).

In addition, 40 fathers were typed at 1:5 for the $\mathrm{Gm}$ antigens that they lacked at 1:30: $20 \mathrm{Gm}\left(\mathrm{f} ; \mathrm{b}^{0}, \mathrm{~b}^{\mathbf{1}}, \mathrm{b}^{\mathbf{8}}\right), 12 \mathrm{Gm}\left(\mathrm{a} ; \mathrm{b}^{\mathbf{0}}, \mathrm{b}^{\mathbf{1}}, \mathrm{b}^{\mathbf{3}}\right)$, $7 \mathrm{Gm}(\mathrm{a}, \mathrm{x} ; \mathrm{g})$, and $1 \mathrm{Gm}(\mathrm{a} ; \mathrm{g})$. All fathers who were negative for an allotype at 1:30 in the standard test were also negative for the allotype in the endpoint titration assay when tested at 1:5 against six serial dilutions of the allotype antisera.

Finally, in only 1 case, family 960 , is the phenotype inconsistent with the expected pattern of inheritance. Mother 960 has both $\mathrm{G} 1 \mathrm{~m}(\mathrm{f})$ and $\mathrm{G} 3 \mathrm{~m}(\mathrm{~g})$. Her child could receive

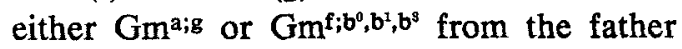
and pass to her either $\mathrm{G} 1 \mathrm{~m}(\mathrm{f})$ or $\mathrm{G} 3 \mathrm{~m}(\mathrm{~g})$ but not both.

\section{Discussion}

The close agreement between the theoretical and observed frequencies of paternal antigen in cord serum suggests that all newborns produce their own immunoglobulin $\mathrm{G}$ at very low levels. The identity of maternal and cord phenotypes at 1:30, and the higher concentrations of $\mathrm{IgG}$ in cord plasma as compared to the mother $[1,10]$, is strong evidence that maternal antibody is the largest component of the fetus's IgG pool. In addition, the data document a mosaic distribution of fetal IgG subclasses in the mother and the cord.

The mosaic pattern of paternal antigen in cord and mother might have a number of explanations. First, it might be a technical artifact. The three $\mathrm{G} 3 \mathrm{~m}(\mathrm{~b})$ allotype antigens might be present in each case but the assay fails to detect all of them. The avidity of antiallotype antibodies for antigen varies, this making one antiserum with a higher avidity more susceptible to inhibition by low concentrations of cord $\mathrm{Gm}$ protein than a serum with low avidity. Yet one would expect to find a consistent pattern in the presence of paternal antigen if this were true; and one does not.

For instance, the paternal G3m(b $\left.b^{1}\right)$ antigen seems to be found at high dilution, $1: 30$, in the absence of the other two, and is usually present in the cord at low dilution in the ETI test when the $\mathrm{G} 3 \mathrm{~m}(\mathrm{~b})$ complex is inherited. The next most frequent antigen in the complex is the $\mathrm{G} 3 \mathrm{~m}\left(\mathrm{~b}^{0}\right)$ whereas $\mathrm{G} 3 \mathrm{~m}\left(\mathrm{~b}^{\mathrm{s}}\right)$ appears least often. This would suggest that the order of avidity of the antiallotype sera is: anti-G3m( $\left.b^{1}\right)$, anti-G3m( $\left.b^{0}\right)$, and anti-G3m( $\left.b^{3}\right)$. But how does one explain mother-cord pair 1097 in which $\mathrm{G} 3 \mathrm{~m}\left(\mathrm{~b}^{3}\right)$ is detected in the cord but only $\mathrm{G} 3 \mathrm{~m}\left(\mathrm{~b}^{1}\right)$ in the mother? Given that anti-G3m( $\left.b^{\mathrm{s}}\right)$ has the lowest avidity, and the linked $\mathrm{G} 3 \mathrm{~m}\left(\mathrm{~b}^{1}\right)$ and $\mathrm{G} 3 \mathrm{~m}\left(\mathrm{~b}^{0}\right)$ are also present, then the assay should detect all three allotypes.

Differences in avidity also would not explain the patterns of families 954,1092 , and 
1102. In 954 and 1102 the mothers are both $\mathrm{G} 1 \mathrm{~m}(\mathrm{a}+)$ and $\mathrm{G} 3 \mathrm{~m}\left(\mathrm{~g}_{+}\right)$, whereas the cords are $\mathrm{G} 1 \mathrm{~m}(\mathrm{a}-)$ and $\mathrm{G} 1 \mathrm{~m}(\mathrm{~g}+)$. Mother 1092 is also positive for both allotypes but the cord is $\operatorname{G1m}\left(\mathrm{a}_{+}\right)$and $\mathrm{G1m}\left(\mathrm{g}_{-}\right)$. If the alleles are linked in a haplotype, $\mathrm{Gm}^{\mathrm{a} ; \mathrm{g}}$ or $\mathrm{Gm}^{\mathrm{a}, \mathrm{x} ; \mathrm{g},}$, then both antigens should be present. Differences in avidity would preferentially detect one and not the other in each of three families. If the anti-Gm(a) serum had a higher avidity, one would expect $\mathrm{Gm}\left(\mathrm{a}_{+} ; \mathrm{g}_{+}\right)$, $\mathrm{Gm}(\mathrm{a}+; \mathrm{g}-)$, but not $\mathrm{Gm}\left(\mathrm{a}-; \mathrm{g}_{+}\right)$, if in fact both linked genes were being expressed in the cord. In the same way, if the anti-G3m(g) serum were more avid, then one would not expect the $\mathrm{Gm}(\mathrm{a}+; \mathrm{g}-)$ phenotypes. Differences in avidity, or the ability to be inhibited by low levels of $\mathrm{Gm}$ antigen, do not seem to be an adequate explanation for the mosaic pattern of phenotypes.

This leads to the second interpretation of the data: that a certain amount of the heterogeneity of expression is the result of the immature immune system in which some, but not all, of the immunoglobulin loci are switched on. Consistent with this explanation are cords 958, 970, 1107, 1114, 1123, 973,1013 , and 1097 in which evidence is found for the inheritance of a haplotype but all of the antigens are not present.

Failure to express an inherited antigen would not, however, explain the curious pattern found in the transplacental distribution of fetal IgG in the mother and cord sera. Fetus 1102, for example, has a portion of his IgG3 while all of his detectable G1m(a+) IgG1 is in the mother. Fetus 1092 lost all of his $\mathrm{G} 3 \mathrm{~m}(\mathrm{~g}+) \mathrm{IgG3}$ and retained part of his G1m(a+) IgG1. Because a number of reports have substantiated that all four subclasses of $\mathrm{G}$ immunoglobulin can cross the placenta $[8,9]$, the data suggest that the fetus can selectively retain and transfer different IgG subclasses.

This would be a satisfactory explanation for antigens on different subclass molecules but would shed little light on the particulate transfer of antigens in the $\mathrm{Gm}(\mathrm{b})$ complex across the placenta. All of the $G m\left(b^{0}, b^{1}, b^{3}\right)$ antigens are on the same molecule of the same subclass, IgG3, but they are found independently of one another in families 973, 1036 , and 1097 . If the assay is detecting all of the antigens that are present, then no satisfactory explanation exists for this phenomenon. Even if the immune system is immature, and only two antigens are expressed, they both should be found on the same molecule and travel together in either direction across the placenta.

Indeed, the presence of paternal antigen in the mother is an enigma for another reason. The maternal whole blood volume is some 10 times that of the infant who is manufacturing only small amounts of his own $\mathrm{IgG}$, so small that a very sensitive technique is needed in most cases to detect it. Yet the autologous IgG of the cord is present in the mother in sufficient amounts that it can be detected. The inhibition titer of paternal antigen in some mother-cord pairs is actually greater in the maternal serum, though, because of the dilution effect of the anticoagulant, it is difficult to give proper weight to this observation.

The most interesting observations in the data, if one can exclude technical artifact, are those trios in which paternal antigen is found in the mother but not in the fetus. Such a distribution of $\mathrm{IgG}$ is evidence for a mechanism by which the fetus selectively transfers his own IgG to the mother against a strong concentration gradient. Cords, on the average, have $1 \frac{1 / 2}{2}$ to 2 times more ma- 
ternal immunoglobulin per $100 \mathrm{ml}$ than do the mothers [1]. This has led to the suggestion that mothers have an enzymatic mechanism that pumps IgG into the fetal circulation and maintains the gradient [5]. An alternate or complementary explanation is offered by the present study: that the fetus retains maternal immunoglobulin while selectively transferring autologous antibody in the opposite direction. Only elucidation of the particular enzymatic mechanisms at work in maternal-fetal IgG transfer will clarify which of the two, fetal retention or maternal transfer, plays the larger role in the fetus. Why the fetus would simultaneously and selectively transfer relatively large amounts of autologous IgG to the mother, is without explanation.

Finally, the problems raised here call for a new, more sensitive technique for their solution, the radioimmunoassay. Although the endpoint inhibition test is very good, it yields only a qualitative, yes or no, answer as to the presence of paternal antigen in the mother and cord plasma. A solid phase radioimmunoassay for the $\mathrm{Gm}$ antigens would provide a sensitive quantitative and qualitative tool that could be used to measure the amount as well as the order of appearance of paternal antigen in the cord and would undoubtedly help determine whether the mosaic of $\mathrm{Gm}$ allotype in the mother and cord sera is genuine.

\section{Acknowledgment}

Dr. Harvey Mohrenweiser generously made the blood specimens of the neonates and their parents available for this study.

\section{References}

1 Allansmith, M.; McClellan, B. H.; Butterworth, M., and Maloney, J. R.: The development of immunoglobulin levels in man. J. of Pediatrics 72: 276-290 (1968).

2 Bronnestam, R. and Nilsson, S. B.: Gamma globulin groups $(\mathrm{Gm})$ of mothers and their new-born infants. Vox Sang. 2: 316-319 (1957).

3 Daveau, M.; Rivat, L.; Ropartz, C., and Fessard, $\mathrm{Cl}$.: $\mathrm{Gm}$ and Inv allotypes in premature infants. Biomedicine 23: 23-27 (1975).

4 Fudenberg, H. H. and Fudenberg, B. R.: Antibody to hereditary human gammaglobulin $(\mathrm{Gm})$ factor resulting from maternal-fetal incompatibility. Science 145: 170-171 (1964).

5 Kohler, P.F. and Farr, R. S.: Elevation of cord over maternal $\mathrm{IgG}$ immunoglobulin: evidence for an active placental IgG transport. Nature, Lond. 210: 1070-1071 (1966).

6 Lawler, S. D.: A genetical study of the Gm groups in human serum. Immunology 3: 90-94 (1960).

7 Martensson, L. and Fudenberg, H. H.: Gm genes and $\gamma_{G}$-globulin synthesis in the human fetus. J. Immun. 94: 514-520 (1965).

8 Mellbye, O. J. and Natvig, J. B.: Presence and origin of human IgG subclass proteins in newborns. Vox Sang. 24: 206-215 (1973).

9 Ropartz, C.; Rivat, L. et Rousseau, P.-Y.: La transmission des facteurs $\mathrm{Gm}$ et Inv de la mère à l'enfant nouveau-né. Annls Génét. 8: 39-43 (1965).

10 Williams, R.C. and Gershowitz, H.: IgG levels in mother-father-cord trios. Vox Sang. 37: 103106 (1979).

Received: December 28, 1978

Accepted: March 19, 1979

Dr. H. Gershowitz, Department of Human Genetics, The University of Michigan Medical School, 1137 East Catherine Street, Ann Arbor, MI 48109 (USA) 